\title{
RECONHECIMENTO, PARTICIPAÇÃO POLÍITICA E MERCADO ÉTNICO: LIDERANÇAS QUILOMBOLAS E O EMPODERAMENTO FEMININO
}

\author{
RECOGNITION, POLITICAL PARTICIPATION AND ETHNIC MARKET: \\ QUILOMBOLAS LEADERSHIP AND WOMEN EMPOWERMENT
}

Divania Cássia da Silva ${ }^{1}$

\section{RESUMO}

Este artigo apresenta uma discussão sobre a relação entre os processos políticos e as lideranças quilombolas. A pretensão aqui é entender como as transformações sociais, ocorridas dentro do arcabouço político estruturado nas últimas décadas no país, podem ter se configurado enquanto oportunidades políticas, sobretudo para a constituição e inserção de lideranças quilombolas em novos espaços sociais. Aliado a tais transformações estruturais, entender como essas líderes mulheres se apropriam de saberes e habilidades acumuladas em suas trajetórias e as reconvertem em recursos sociais e políticos. Assim, por meio de questionários e entrevistas abertas, este artigo demostra que as lideranças femininas da Serra das Viúvas desenvolvem por meio de suas lutas identitárias estratégias de projeção social e política, em meio a arenas de disputas de poder, que por sua vez, lhes conferem visibilidade dentro e fora da comunidade. Constata-se assim, que por meio de seu artesanato étnico, essas lideranças acionam diversificados recursos e habilidades e os reconvertem em estratégias políticas de empoderamento para diferentes inserções sociais.

Palavras-chaves: Liderança Feminina; Reconhecimento; Quilombolas; Empoderamento.

\begin{abstract}
This article presents a discussion on the relationship between political processes and quilombola leadership. The intention is to understand how the social transformations within the political framework structured in the last decades in the country may serve as political opportunities, especially for the development and insertion of quilombola leaders in new social spaces. Combined with these structural transformations, this study was also designed to advance the understanding on how these women leaders use the knowledge and skills accumulated in their trajectories as social and political resources. By using questionnaires and open interviews, this research demonstrates that the Serra das Viuvvas' women leaders develop social and political projection strategies through their identity and power struggles, which in turn give them visibility inside and outside the community. It is clear that, through their ethnic craftsmanship, these leaders access diverse resources and skills and convert them into political empowerment strategies for different social roles.
\end{abstract}

Keywords: Women leadership; Recognition; Quilombolas; Empowerment.

\footnotetext{
${ }^{1}$ Atualmente é Professora Adjunta da Universidade Federal de Alagoas - UFAL. Doutora e Mestra em Sociologia pela Universidade Federal de Sergipe-UFS. e-mail: divaniacassia@gmail.com
} 


\section{nevitate

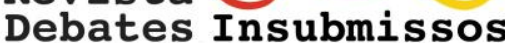

\section{INTRODUÇÃO}

Este artigo tem como objeto de estudo a relação entre reconhecimento e justiça social. Tal análise se volta para a comunidade quilombola Serra das Viúvas, situada no sertão de Alagoas. É interesse deste estudo compreender como as orientações que permeiam as ações de luta por reconhecimento conduzidas pelas líderes mulheres dessa comunidade, direcionam suas inserções em diferentes espaços sociais, políticos e econômicos junto a outros grupos e instituições. O que se pretende é analisar em que medida a luta por reconhecimento político desenvolvida na comunidade Serra das Viúvas interfere nas transformações da situação de desigualdade étnico-racial e cultural vivenciada por esse coletivo.

Este artigo faz parte de uma pesquisa mais ampla acerca dos processos políticos e as participações coletivas. Enquanto objeto de minha tese - Reconhecimento, mercado étnico e participação política: a questão quilombola e a comunidade Serra das Viúvas, busquei relacionar as transformações estruturais no arcabouço político brasileiro e as diversificações no repertório de ações políticas dessa comunidade. Desse modo, trago para este artigo, uma discussão mais focada nas lideranças desse coletivo e suas formas de agir em torno de seus bens simbólicos, o artesanato étnico, em meio a disputas políticas e projeções por espaços de poder.

A comunidade Serra das Viúvas possui mais de 100 famílias, a maioria liderada por mulheres lavradoras, extrativistas e artesãs, que fazem dos produtos derivados de recursos naturais seus sustentos e de suas famílias. Em 6 de outubro de 2009, receberam da Fundação Cultural Palmares (FCP) o certificado de autorreconhecimento. Em finais da década de 1990, início dos anos 2000, como resultado de estímulos externos, as mulheres da comunidade decidiram se organizar para desenhar um empreendimento comunitário que sistematizasse a produção e comercialização do artesanato. A iniciativa é liderada por Marlene e Belinha, filhas de dona Maria Isabel (Mãe Bela). Assim, a comunidade local fundou, em 16 de outubro de 2010, a Associação de Mulheres Artesãs Quilombolas Serra das Viúvas (Amaqui), cuja sede funcionava inicialmente, na casa de farinha de Mãe Bela. Essas mulheres se referem aos objetos confeccionados para a venda em termos de "artesanato quilombola". 


\section{Revista \\ Debates Insubmissos}

Essa realidade de reconhecimento e institucionalização da comunidade quilombola Serra das Viúvas, aqui brevemente problematizada, compõe inúmeras realidades étnico raciais latentes hoje nas sociedades tidas como multiculturais. Nas últimas décadas, essas sociedades com pluralidades culturais, étnicas e raciais (TYLOR, 1992, 1994; YONG, 2000) têm despertado interesse analítico em diferentes áreas de conhecimento da Antropologia, Sociologia, assim como da Ciência Política, dentre outras. Desse modo, os debates travados dentro e entre essas áreas de estudo acerca da justiça social e participação política apontam para o reconhecimento como um importante elemento a ser compreendido nesse cenário de mobilizações sociais. Nessa vertente, países latino-americanos, como o Brasil, acompanhando diretrizes e orientações internacionais em torno de um desenvolvimento mais alternativo, passam a desenvolver políticas de inclusão social, étnica e cultural, impactando o arcabouço estrutural do Estado. Seguindo essa perspectiva, tais realidades políticas e sociais em transformação têm oferecido fecundos cenários de mobilizações coletivas em torno de participação política e inclusão social, evocando, assim, diferentes correntes de análise, no intuito de apreender suas lógicas de ação.

Desse modo, seguindo orientações jurídico-normativas internacionais, o Brasil passa a desenvolver uma série de políticas públicas inclusivas a partir do início dos anos 2000, transformando completamente o cenário político e social do país. Assim, inclinações para um etnodesenvolvimento (STAVENHAGEN, 1985; SILVA, 2011) irão compor uma série de ações estruturais efetivadas pelo Estado, caracterizando tais circunstâncias como "singulares aberturas políticas" para a organização e desenvolvimento de determinados grupos tidos como marginalizados de certos direitos sociais e políticos. Historicamente, os movimentos sociais em torno tanto de lutas por reconhecimento quanto por mobilizações por garantias materiais e redistributivas travam um embate conflitivo com o Estado. De modo que, normalmente, somente por meio dessas lutas que tais grupos conseguem garantir seus direitos ao reconhecimento político e identitário, bem como, em muitos casos, também direito à redistribuição de bens materiais.

O cenário político nacional, aqui brevemente problematizado, parece apontar para um contexto específico de oportunidades políticas (MCADAM; TARROW, 1996, 2011) em que 


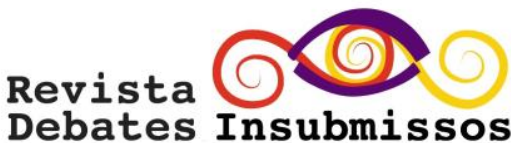

determinadas mobilizações, e até mesmo constituição de novos movimentos sociais, acontecem viabilizados por transformações nas condições sociais e políticas. Essa dinâmica de institucionalização de políticas diferenciadas, nesse caso afirmativas, ocorre num processo em que não só os movimentos sociais são impactados por essas transformações políticas, mas também são causadores de modificações nesses novos cenários. Percebe-se assim a complexidade que envolve o debate sobre reconhecimento e participação política.

Desse modo, as dinâmicas relacionais entre os diferentes atores que compunham as redes de relação dessa comunidade sugerem interessantes formas de conduzir as circunstâncias em torno de suas mobilizações, sejam elas de garantias, sejam elas de ameaças. As participações políticas das lideranças da Serra permitiram a esse coletivo diferentes inserções sociais, ampliando seus espaços de ação e influência. Aproximações junto a diferentes atores tornamse importantes elementos constituintes dessas relações em transformação, ou seja, as interações entre essas diversificadas realidades inseridas em contextos específicos conduzem a formas de agir, que sugerem ressignificações das mobilizações identitárias desenvolvidas pela comunidade.

Tornou-se assim, importante para este artigo, entender as circunstâncias nas quais estão inseridos esses atores, objetivando identificar possíveis relações causais entre fatores diversos e adversos envolvidos nessa realidade em transformação. Seguindo tal lógica, este estudo aponta para conexões entre seus pertencimentos étnicos e territoriais e suas movimentações políticas em torno da justiça social. Assim, a preservação do território da Serra das Viúvas é estratégica, sobretudo para manter as diferentes dinâmicas grupais responsáveis pela coesão e preservação desse coletivo, como é o caso de seu artesanato local. Embora existam circunstâncias conflitivas em torno da terra, o grupo apresenta estratégias eficientes de manter suas mobilizações identitárias e ainda, reafirma-se diante de seu território reivindicando dessa forma, seus espaços de pertencimentos culturais. 


\section{DISCUSSÃO TEÓRICA}

Com efeito, este artigo está pautado numa discussão teórica maior quanto ao reconhecimento e justiça social (AXEL HONNETH, 2003; RENAULT, 2004; TAYLOR, 1992, 1994; SANDEL, 1982; WALZER, 1983; YONG, 2000), como também nas discussões teóricas em torno da participação política e processos políticos (MCADAM, 1996; TILLY, 1996; TARROW, 2013; DIANI, 1992). Este estudo partilha do ponto de vista teórico de que há uma redefinição dos limites relacionais e identitários entre esses atores, quando submetidos a possíveis situações conflitivas e adversas, de modo que se constroem alternativas a tais modificações conjunturais (TILLY, 1996; DIANI, 1992).

Esta pesquisa se apoia em estudos sobre comunidades negras rurais, remanescentes quilombolas, movimentos sociais e participação política (ARRUTI, 2006; ANJOS, 2008; BOYER, 2009; LEITE, 1999; ALMEIDA, 2004; MELLO, 2019; NEVES, 2005; 2018; 2019; RAMOS, 2009) que sugerem ter ocorrido no país, nas últimas décadas, uma reconfiguração do arcabouço estatal, de modo que as condições favoráveis promovidas pelo Estado refletiram em contextos de oportunidades de inserção política e social para esses grupos organizados (LEITE, 2000). Historicamente, os movimentos sociais em torno de lutas por reconhecimento e de mobilizações em busca de garantias materiais e redistributivas travam um embate conflitivo com o Estado. Normalmente, somente por meio dessas lutas que tais grupos conseguem garantir seus direitos ao reconhecimento político e identitário, bem como, em muitos casos, também direito à redistribuição de bens materiais.

Desse modo, lideranças desses coletivos étnicos despontam em condições de visibilidade política e social em meio a recursos específicos. Assim, de que forma, acúmulos de recursos sociais e saberes ao longo de suas trajetórias, influenciaram e contribuíram para ações de organização e luta de caráter mais localizadas. Frequentemente, estudos sobre a questão de gênero, mais precisamente voltados para as participações políticas de mulheres em mobilizações sociais, apontam para uma relação entre domínios de saberes e empoderamento feminino (CRENSHAW, 2002; NEVES, 2019; TUBALDINI, 2010). 
Assim, essas mulheres despontam em circunstâncias de empoderamento como líderes de demandas políticas e econômicas dentro de seus grupos (NEVES, 2019). Com isso, os discursos, as interações, são reconhecidos como elementos constituintes das relações sociais, mas somente validados, com efeito, mediante condições exteriores a esses discursos, às consciências individuais (BOURDIEU, 1996). Sendo assim, o que se pretende é, entender os elementos envolvidos na constituição desse status de liderança feminina em uma realidade em que, diferentes pertencimentos identitários parecem se entrelaçar.

\section{METODOLOGIA}

Para efetivação desta pesquisa foram desenvolvidos alguns procedimentos metodológicos no intuito de complementaridade das informações aqui coletadas. Assim, foram aplicados ao todo 50 questionários ao longo da pesquisa objetivando assim, levantar um perfil socioeconômico e político dessa comunidade. Também, foram realizadas entrevistas abertas com moradores e lideranças da comunidade, além de outros atores ligados ao grupo, como lideranças de instituições governamentais e não governamentais, entre outros. Foram ao todo 17 entrevistados ao longo da pesquisa.

\section{ARTESANATO ÉTNICO, LIDERANÇA QUILOMBOLA E EMPODERAMENTO FEMININO NA SERRA DAS VIÚVAS}


Figura 01 - Belinha, liderança quilombola da Serra das Viúvas, filha de Mãe Bela e irmã de Marlene, concedendo entrevista para rede de televisão local.

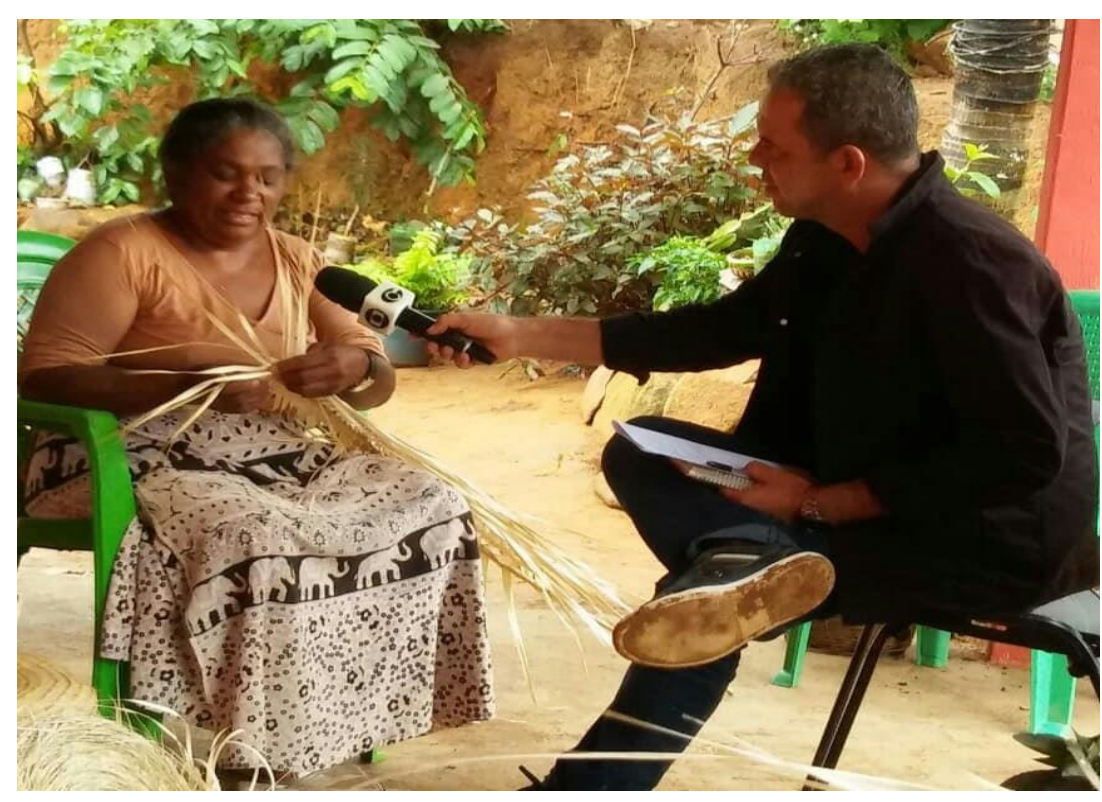

Fonte: Amaqui, 2014

A liderança feminina na Serra das Viúvas é notória nessa realidade coletiva. O destaque aqui não se resume ao fato de serem elas, as artesãs, responsáveis pela Amaqui, mas também serem responsáveis pelas diretrizes das ações políticas da comunidade. Portanto, torna-se importante para este artigo entender as lógicas envolvidas nas diretrizes propostas por essas lideranças em seus repertórios de luta por reconhecimento étnico e racial. Desse modo, é preciso pensar como a ação coletiva reflete nas condutas individuais e na produção e reprodução da vida cotidiana destes atores sociais. Pensar, ainda, de que forma possíveis retribuições simbólicas e materiais são acessadas por essas lideranças.

O entendimento deste artigo perpassa pela compreensão do fenômeno do engajamento político dessas lideranças enquanto resultante de fatores sociais, políticos, econômicos e culturais. O espaço que a mulher ocupa enquanto liderança na Serra das Viúvas parece indicar fatores específicos presentes na gênese da comunidade, que estariam relacionados às condições objetivas que abarcariam o grupo. Não caberia, assim, afirmar a liderança feminina na Serra tão somente pelo fato de ser um grupo assumidamente diferenciado, etnicamente e culturalmente 


\section{Revista \\ Debates Insubmissos}

falando. Faz-se necessário buscar entender os elementos envolvidos na constituição desse status de liderança feminina em uma realidade em que diferentes pertencimentos identitários parecem se entrelaçar. Essas mulheres demonstram deter saberes tradicionais em diferentes dimensões da vida, conhecimentos culturais ligados à religiosidade, ligados ao artesanato, conhecimentos artísticos ou mesmo médicos quando trazem seus saberes sobre ervas medicinais ou perpetuam a arte das benzedeiras. Assim, despontam em circunstâncias de empoderamento como líderes de demandas políticas e econômicas dentro de seus grupos (NEVES, 2019).

Frequentemente, estudos sobre a questão de gênero, mais precisamente voltados para as participações políticas de mulheres em mobilizações sociais, apontam para uma relação entre domínios de saberes e empoderamento feminino (CRENSHAW, 2002; NEVES, 2019; TUBALDINI, 2010). A presença de certo grau de invisibilidade presente nesses espaços envolve questões relativas a mulheres marginalizadas por seu gênero, cor, etnia, religião. Ao mesmo tempo, estar inserida em tais circunstâncias pode fornecer trunfos, saberes, conhecimentos que direcionam para certo reconhecimento e status diferenciado.

Ao analisar a gênese da Serra das Viúvas, foi possível se apropriar de informações que podem contribuir com algumas compreensões sobre o lugar que a mulher ocupa hoje nesse grupo. Por meio dos relatos orais, ficou evidenciado desde cedo que a presença de mulheres sempre foi majoritária. Do total de entrevistas e questionários aplicados na comunidade, menos de $10 \%$ foram com homens. Não só pelo fato de serem minoria na comunidade, mas também por demostrarem certos constrangimentos em conversar com pessoas estranhas ao grupo. Nesse sentido, é importante frisar que a grande maioria dos homens da comunidade desenvolve trabalhos fora do município e também do estado, no que popularmente é conhecido como "trecho" - trabalham no trecho. Não saberia relacionar de forma determinante se o número maior de mulheres do que de homens estaria relacionado às origens do grupo. No entanto, é possível fazer algumas reflexões relacionais acerca dessa realidade:

\footnotetext{
Bom, essa sua pergunta... bom, eu vou respondê por mim. Num sei as outra, mas eu vou falá o que eu penso. Aqui derna dos tempo atrás de minha vó e minha bisavó, isso é que minha mãe me falava. Quando Lampião matou os home daqui, as muié teve que se virá. Foi tratá da cana e foi pro engenho. Num é?! Se não, como é que ia comer? Então, ela conta que, as veis, andavam o dia todo pra fazê o manejo da cana e das outra plantação dono do engenho, né?! Que era o avô de Maurício. Mas ela nunca
} 


\section{Revista \\ Debates Insubmissos}

deixou de fazer o artesanato e ensinar pra minha mãe e minha mãe ensinou pra gente e assim vai. Os mais jove vai aprendeno e passano. Isso eu digo é de minha vó (ENTREVISTA COM LIDERANÇA DA COMUNIDADE SERRA DAS VIÚVAS, REALIZADA DURANTE TRABALHO DE CAMPO).

O fato de os homens terem sido assassinados pelos cangaceiros há décadas, segundo as memórias e relatos orais dos moradores da Serra, pode indicar a ressignificação que essas mulheres passaram a fazer de seus papéis nesse coletivo. Com a ausência súbita de seus companheiros e prováveis provedores de suas subsistências, as poucas famílias residentes tiveram que reordenar suas lógicas de organização interna, de modo que as mulheres passariam a desempenhar um papel crucial na sobrevivência e resistência do grupo, ampliando seus afazeres para além dos limites caseiros. Os trabalhos na lavoura, na plantação e na colheita, no próprio engenho e, no caso da Serra das Viúvas, na produção do artesanato se tornam atividades inerentes às rotinas dessas mulheres. Desse modo, o empoderamento dessas líderes quilombolas se liga às suas referências históricas, na medida em que constituem uma trajetória de luta e contraposição dos espaços de invisibilidade, opressão e desigualdade (CRENSHAW, 2002).

Nessa perspectiva, é possível relacionar prováveis fatores causais em meio a condições objetivas, buscando dar sentido a determinadas subjetividades nas ações (BOURDIEU, 1996; 1998) ou seja, é possível entender o protagonismo que as mulheres passam a desempenhar na comunidade desde cedo. Nesse momento inicial, suas ações voltadas para os trabalhos laborais junto à lavoura e também na produção do açúcar e rapadura no engenho possuíam um significado de maior importância em detrimento do artesanato, tendo em vista a lógica e organização do sistema político-econômico vigente. Mesmo que ao longo do tempo um número maior de homens passa a ocupar a Serra, as mulheres continuam a perpetuar essa nova lógica de organização interna, em que os limites fronteiriços entre liderar e ser liderada já são colocados em xeque.

Assim, as articulações entre interdependências e conexões sociais tornam o fenômeno da participação política passível de ser analiticamente apreendido. Enfatizar as ligações entre mudanças na organização estrutural da sociedade e mudanças na estrutura do comportamento nos leva ao entendimento de que as interdependências nas quais os indivíduos estão inseridos também fazem parte da formação das estruturas interiores da personalidade (ELIAS, 2001). 


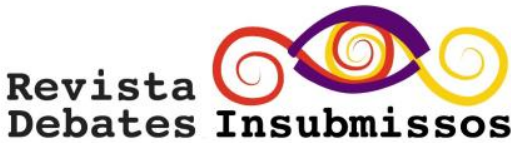

Com isso, as internalizações que as mulheres da Serra das Viúvas fizeram a partir de suas experiências pessoais, em meio às circunstâncias estruturais nas quais foram envolvidas, permitiram uma construção perceptiva acerca do mundo e da vida que vai lhes aproximando do status de liderança quilombola que hoje ocupam no grupo.

Desse modo, circunstâncias peculiares em relação às origens da comunidade fornecem pistas sobre os posicionamentos sociais e políticos que essas líderes mulheres passam a assumir dentro e fora dos limites do grupo. A partir do momento em que as mulheres se inserirem em outros espaços, diferentes relações sociais e políticas passam a fazer parte de suas vidas. Com tais inserções variadas, elas agregam em suas trajetórias conhecimentos e habilidades que só foram possíveis em detrimento de mudanças em suas condições objetivas. Com essas entradas em novos espaços de convívio e trabalho, as mulheres da comunidade ampliam, ainda que em alguns momentos de forma involuntária, suas redes de amizade.

Com isso, as mulheres da Serra das Viúvas, ao longo de suas trajetórias, envolvem-se com movimentações sociais e políticas variadas. Desde seus envolvimentos com associações e sindicatos rurais, elas também tomam a frente da construção da própria sede das associações da comunidade, tanto a de moradores de forma geral, que foi a primeira ser constituída, quanto a construção da Amaqui. Além disso, as lideranças femininas se inseriram em mobilizações políticas direcionadas para seu reconhecimento quilombola e também lideraram ações de caráter reivindicatório redistributivo. Estudos sobre populações rurais e os espaços de lideranças femininas (NEVES, 2019; SOUZA; ARAÚJO, 2014) têm demonstrado que existe uma relação entre o ativismo dessas mulheres nos processos mobilizatórios dos movimentos sociais no campo e o seu envolvimento em demandas redistributivas, as mudanças nas relações de poder em espaços públicos e em seus círculos de convívio mais pessoais. Com efeito, elas vão ocupando por meio dessas ações posicionamentos que as projetam dentro do grupo como pessoas que demonstram "competências" para a comunidade alcançar o sucesso de lutas travadas.

Essas competências e habilidades - muitas conferidas a partir de suas vivências culturais e sociais - objetivamente passam a ser reconvertidas em recursos sociais, quando as oportunidades políticas contribuem com certas flexibilizações das circunstâncias em torno do 
grupo. Durante os últimos anos de desenvolvimento da comunidade, as lideranças femininas abraçaram diferentes lutas sociais. Nesse bojo de mobilizações políticas, as lutas em torno da reivindicação identitária da comunidade como remanescente de quilombo se destacaram como um eixo norteador de suas movimentações em torno de outras dimensões da vida da comunidade.

O processo de reconhecimento político da categoria identitária quilombola e o processo de institucionalização do artesanato por meio da Amaqui, embora ocorram em momentos distintos, coexistem em suas interdependências. Com a amplitude das movimentações do grupo em torno do reconhecimento quilombola, ele passa a perceber essa "diferença identitária e étnica" como uma forma de lhe conferir "status social" junto a instituições e grupos diversos. Essa percepção em torno de sua apropriação de autorreconhecimento é transferida também para seu artesanato étnico:

Assim, o nosso artesanato sempre foi importante. A gente sempre foi conhecida aqui como as artesãs da Serra. Mas, quando a gente virou quilombola, aí já muda um pouco, né?! Assim, eu quero dizê que agora o artesanato, também é quilombola. Então, você sabe, né?! Essas coisas ficam diferentes. Essa coisa de sê de uma comunidade tradicional, né, é assim que se diz, né?! E aqui, sê uma comunidade tradicional e quilombola, então isso só trais mais valor pras peças (ENTREVISTA COM LIDERANÇA DA COMUNIDADE SERRA DAS VIÚVAS, REALIZADA DURANTE TRABALHO DE CAMPO).

Figura 2 - Artesanato quilombola da Serra das Viúvas em exposição na feira artesanal fora do estado.

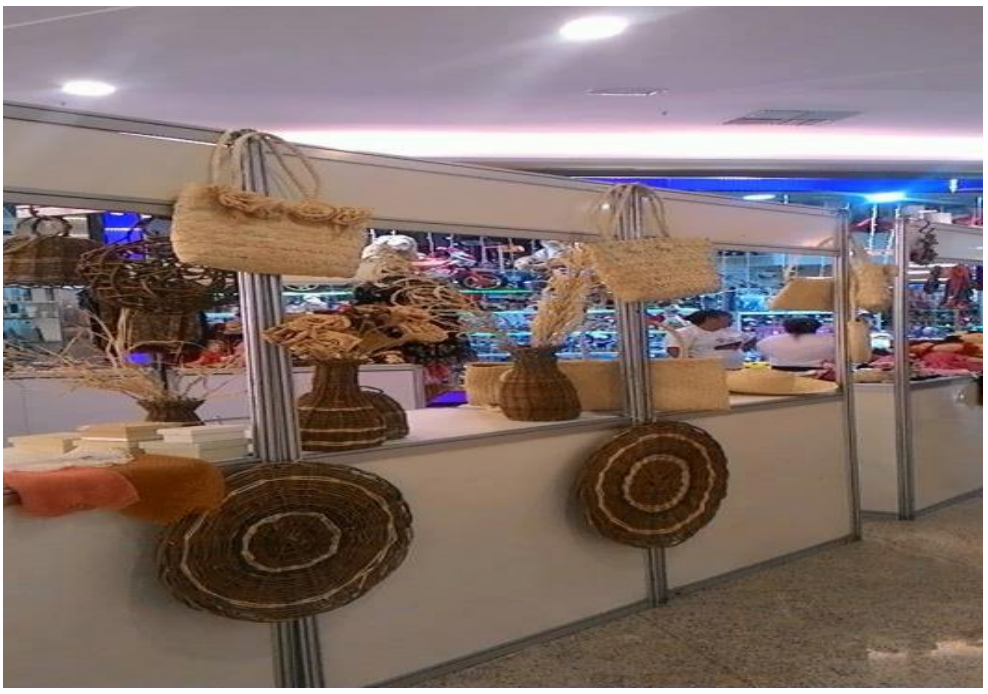

Fonte: Amaqui. 


\section{Revista \\ Debates Insubmissos}

Ao reconhecer a importância de uma atribuição categorial para a projeção do artesanato local, a liderança confere um significado de conexão entre esses processos. Ao passo que a comunidade se aproximava da efetivação institucional de sua Associação de Mulheres Artesãs Quilombolas (Amaqui), colocava para o grupo a importância de definir um enquadramento categorial para si; processos que se desenvolveram de forma relacional, no sentido de interdependentes e coexistentes. Desse modo, no caso da Serra das Viúvas, tornar-se quilombola significou, sobretudo, tornar-se "quilombola artesã".

Essa dinâmica de status categorial que se projeta nas diferentes dimensões do grupo é condizente com uma atmosfera de etnodesenvolvimento em que as interconexões entre diferentes esferas sociais acontecem (STAVENHAGEN, 1984). Isso significa que a preservação e a autonomia dessas comunidades não sugerem isolamento ou rupturas com as realidades próximas, mas, antes, esses coletivos precisam a partir de suas frequentes e variadas inserções sociais desenvolver estratégias de interação junto a esses novos atores. O que precisa ser pensado por parte do grupo étnico é quais interações devem ser feitas, com quais grupos e instituições e para quais finalidades. Assim, as aproximações ou mesmo distanciamentos podem definir suas possibilidades de se projetar em novos espaços de políticos e de poder.

Portanto, com suas interações com realidades diversas, essas lideranças acessam e internalizam diferentes conteúdos e experiências que irão compor seus repertórios de ações. Interpretam mudanças contextuais como oportunidades ou ameaças, negociam circunstâncias interpretativas que definem conflitos ou soluções e constroem estratégias para direcionar tais contextos (DIANI, 1992); ou seja, imersas nas transformações contextuais vigentes, as lideranças femininas da Serra assimilam e, a partir de seus conhecimentos e competências internalizadas, criam suas próprias percepções da realidade, bem como as estratégias de luta. Existe aqui uma compreensão por parte dessas mulheres de que essa simbiose entre artesanato e a categoria identitária quilombola, mais do que um reconhecimento étnico e racial, pode significar novas inserções sociais e políticas, além de ganhos materiais.

Assim, todas essas transformações na organização interna da comunidade exigiram das artesãs uma ressignificação de suas percepções acerca do seu "fazer artesanato". Em outras palavras, as novas demandas em relação ao artesanato local nos últimos anos, provenientes de 


\section{Revista \\ Debates Insubmissos}

sua projeção no mercado, exigiram que as lideranças artesãs agregassem habilidades já adquiridas ao longo de suas trajetórias com novos conhecimentos adquiridos a partir de suas novas inserções sociais, possibilitadas, por sua vez, por meio de novas redes de amizade. Esse dinâmico cenário norteado por um ethos de etnodesenvolvimento local consiste na elaboração de estratégias de interação com variados atores sociais. Desse modo, o estabelecimento de uma situação de autonomia cultural e produção étnica não sugere isolamento ou negação de novos saberes ligados a novas realidades. O que ocorre, quando passam a existir essas aproximações entre os saberes da mão (RUGIU, 1998) e novos saberes técnicos, é uma avaliação de limites relacionais por parte desses grupos étnicos, ou seja, agregar para ampliar.

Nesse contexto, elas passam a unir um saber tradicional com novas técnicas de conhecimento. O que só foi possível, nesse caso, pela forma que essas lideranças entenderam e projetaram suas lutas em torno do reconhecimento cultural, o novo enriquecendo o tradicional. Isso significa para elas a não descaracterização de seu trabalho artesanal. Os processos de reconhecimento quilombola e o de institucionalização do seu artesanato possibilitaram a essas mulheres artesãs e lideranças ressignificar suas heranças culturais e tradicionais, ou seja, no que diz respeito à perpetuação do "fazer artesanato", houve o entendimento de agregar conhecimento e valor também a partir de processos inéditos ao grupo, resultantes de suas articulações com novos atores sociais. Essa percepção que elas passam a desenvolver do artesanato quilombola perpassa, inclusive, por possíveis ganhos simbólicos como status social ou mesmo ganhos distributivos.

Desse modo, o artesanato da Serra passa a se inserir em uma dinâmica de mercado de bens simbólicos (BOURDIEU, 1996; THOMPSON, 1995), onde passam a ter um valor de mercado quando projetados para além das fronteiras da comunidade, tornando assim, esse artesanato étnico um importante elemento de projeção e coesão do grupo. Assim, o grupo se movimenta em torno de seus pertencimentos étnicos e culturais orientados por meio de sua atividade artesanal que se torna uma fonte de renda alternativa, mas também estratégico trunfo em suas mobilizações políticas nas arenas de disputas por poder e influência social. Dessa forma, o ethus mercadológico em torno de uma categorização identitária e suas produções simbólicas, principalmente em torno do seu artesanato, deve aqui ser compreendido por meio 


\section{neviste

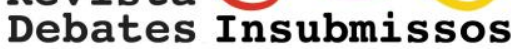

das relações que a comunidade vai estabelecendo ao longo de sua trajetória enquanto quilombola.

Nesse sentido, trazendo ainda o artesanato como eixo norteador de vários processos internos ao grupo, sobretudo relacionados às suas lideranças femininas, faz-se necessário refletir sobre o significado que o artesanato passa a ter em relação a essas mulheres e seus próprios grupos familiares. Os impactos de suas posturas diante das demandas contenciosas ou de oportunidades. Muito interessante perceber como as lideranças femininas se projetaram dentro do grupo enquanto personagens de destaque, a partir de seus recursos sociais e saberes adquiridos em meio às suas inserções diversificadas. Interessante, também, é buscar relacionar tais projeções às suas vivências mais pessoais, no âmbito de seus círculos familiares. Quando questionadas sobre como os homens da comunidade enxergam o trabalho delas como lideranças e como artesãs, algumas líderes chegaram a demonstrar certos constrangimentos ou desinteresse em conversar sobre tal problemática:

Ah... os home daqui pássaro a respitá nóis depois de tudo isso. Eles já respeitava. Mais, depois disso, eles viro que a gente tem força. Se num fosse a gente, num tinha saído esse reconhecimento, não. A nossa associação só foi nóis, as mulhé da comunidade. Pra num dizê que não tem homi ajudano, tem um... [risadas] Verdade, tem um homi na associação. Mais foi nóis que correu atráis de tudo. Até a igreja da comunidade foi nóis que tomô a frente. Então, eles viro que a gente num tá pra brincadeira, viro que a mulhé tem força, né?! (ENTREVISTA COM LIDERANÇA DA COMUNIDADE SERRA DAS VIÚVAS, REALIZADA DURANTE TRABALHO DE CAMPO).

Viche... [risadas] Responde tu, Belinha [risadas]. Na nossa casa, os homi, também respeita nóis. Sabe que a gente também trabalha pra ajuda na casa. Depois que o artesanato começou a dá mais um dinheirinho, né?! Depois da associação, aí eles ficaro mais contente. Passaro a creditar mais. Então, nóis ganha nosso dinheiro, ajuda na casa e assim, nóis vai ajudano a comunidade. Então funciona assim, cada um faz sua parte. Tem uns que qué dá um de valentão, né?! [risadas] Mais nóis tem que entendê isso, também. É homi, né?! [risadas] (ENTREVISTA COM LIDERANÇA DA COMUNIDADE SERRA DAS VIÚVAS, REALIZADA DURANTE TRABALHO DE CAMPO).

A compreensão que essas mulheres expressam sobre o lugar do artesanato na comunidade revela também as percepções que possuem acerca de suas posturas dentro dos grupos de convívio mais pessoais. Elas afirmam existir na comunidade o que seria o reconhecimento dos homens em relação ao importante papel desempenhado por elas. Afirmam, também, a contribuição delas na manutenção e sobrevivência de suas famílias. Relatam, ainda, 


\section{Revista \\ Debates Insubmissos}

a importância de seus trabalhos para ajudar no desenvolvimento e permanência da comunidade. No entanto, quando tentamos extrapolar as fronteiras do coletivo para entender os impactos de tais posicionamentos de líder em suas relações mais pessoais, elas demonstraram posicionamentos de resistência e constrangimentos em relação a essa questão.

Ao se esquivarem de tais diálogos, aparentemente de cunho mais subjetivos e pessoais, as entrevistadas direcionavam as respostas sempre para o viés econômico, ou seja, o reconhecimento de seus trabalhos - sobretudo junto ao artesanato - traz uma contribuição material para a comunidade, que tanto elas quanto o resto do grupo fazem questão de salientar. Entretanto, o reconhecimento simbólico de suas atuações perpassa por outros processos mais complexos e multidimensionais, porque as ações individuais e suas diferentes formas de internalizações (BOURDIEU, 1998) precisam ser objetivadas, buscando entender os sentidos envolvidos nas ações desses atores em questão. Assim, a valoração de suas posturas enquanto líderes mulheres para a comunidade, está refletida em seus relatos por meio de vários exemplos de fatos coletivos pertinentes ao grupo.

No entanto, ao direcionar as questões para o reconhecimento dentro de seus espaços de convivência mais particulares, parece indicar não haver muitos indícios de reconhecimentos de suas posturas de liderança ou, ainda, parece ocorrer constrangimentos pelo fato de entenderem que as dinâmicas familiares e afetivas exigem outros tratos e habilidades que não necessariamente as acionadas por elas no espaço coletivo maior. Além disso, pode haver formas próprias e peculiares de reconhecimento dessa liderança feminina dentro de seus vínculos mais particulares, que talvez os esquemas teórico-metodológicos em questão não tenham conseguido abarcar ainda. Assim, não é objetivo deste artigo se debruçar sobre as relações pessoais e afetivas dessas lideranças, apropriando-se de forma descontextualizada de suas subjetividades, retirando-as de um contexto mais objetivo; pois, compreende-se que a interconexão entre diferentes dimensões da vida e do mundo que tal problemática suscita envolve múltiplas diferenças e desigualdades (CRENSHAW, 2002; TUBALDINI, 2010).

Portanto, o que interessa a este estudo é buscar relações causais que nos ajudem a compreender as inserções dessas mulheres na condição de líderes e os seus impactos diante das diversas dimensões que as envolvem. Com isso, identificar o lugar ocupado por essas mulheres 


\section{Revista \\ Debates Insubmissos}

à frente de seus coletivos em mobilização não significa apontar mudanças estruturais profundas nos papéis de gênero tradicionais, em que a submissão feminina nos espaços privados ou mesmo públicos é a regra (NEVES, 2019). No entanto, é preciso reconhecer que os papéis assumidos por essas lideranças femininas são multifacetados e passíveis de ressignificações acerca de seus posicionamentos nas diferentes dimensões da vida.

Dessa forma, trilhar com equilíbrio a relação entre elementos da subjetividade em meio a circunstâncias objetivas exige foco no tipo de relação causal que se busca compreender. Quando as lideranças trazem exemplos concretos de como identificar suas contribuições e reconhecimento do desenvolvimento da comunidade, sobretudo redistributivo, demostram a clareza que elas possuem acerca de seus papéis em nível de grupo. O que já não se traduz com tanta clareza quando se direcionam as mesmas reflexões para o nível mais interpessoal. Uma delas chega a mencionar que, pelo fato de ser homem, é preciso entender algumas posturas mais intransigentes. Pressupõem-se que existem desafios constantes nas trajetórias dessas mulheres que exigem por parte delas internalizações e ressignificações constantes de suas realidades. Como conectar diferentes conteúdos e saberes em suas práticas cotidianas. Como mediar conflitos e acordos em nível coletivo e entender o impacto de tal postura em dimensões mais particulares de suas vidas, pois suas identidades pessoais e coletivas resultam das interações nas mais diversas esferas sociais, inclusive familiares.

Com efeito, a perspectiva multidimensional parece indicar a necessidade de olhar atentamente para elementos variados presentes nas trajetórias dessas lideranças, que permitam entender seus posicionamentos políticos. $\mathrm{O}$ artesanato, assim, parece ser o eixo norteador de vários processos de mobilização e organização ocorridos dentro da comunidade. Inclusive, como uma referência de identificação para essas lideranças artesãs dentro e fora da comunidade. Não apenas nos seus espaços familiares, elas são vistas e identificadas como mulheres artesãs, mas também fora das fronteiras da comunidade. Dessa forma, o artesanato se projeta enquanto gatilho de orientações pessoais e coletivas em torno de lutas por reconhecimento e possíveis retribuições simbólicas e materiais.

Nessa perspectiva, as formas de participação política das lideranças da Serra das Viúvas demonstram uma complexidade de fatores relacionados, pertencentes a esferas sociais 
diversas, inclusive familiar. Não se trata apenas de apresentar construções categoriais em torno dessas líderes, mas numa perspectiva mais transversal compreender de forma relacional os diferentes fatores envolvidos na constituição e sobrevivência desse grupo, inclusive por meio das ações de suas mulheres artesãs. Desse modo, o que parece acontecer é uma redefinição dos limites relacionais entre esses atores, de modo que a partir de possíveis situações conflitivas e adversas se constroem alternativas a tais modificações conjunturais. Essas lideranças indicam se apropriar, ao longo de suas trajetórias, de saberes e recursos diversos e os reconvertem em estratégias de ação para novas inserções sociais e políticas.

\subsection{Lideranças Quilombolas e Mediação de Diferentes Projetos Identitários}

Figura 03 - Lideranças femininas de diferentes gerações da Serra das Viúvas- AL

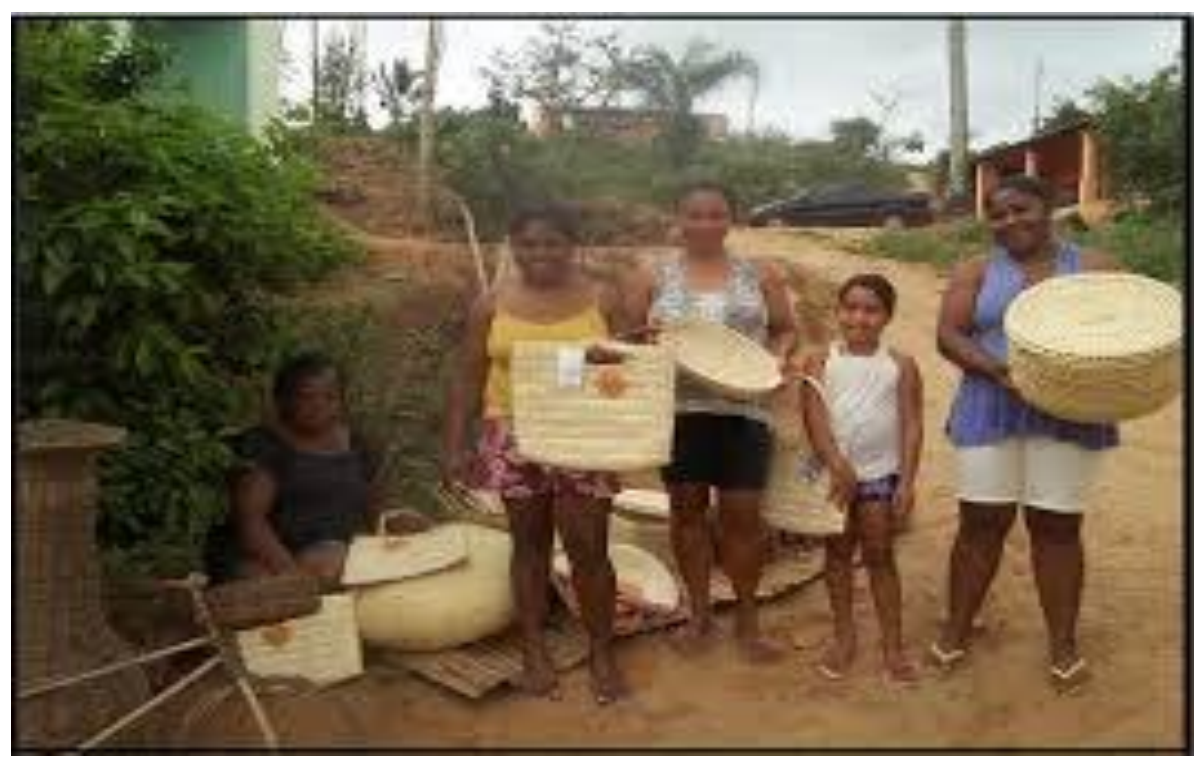

Fonte: Silva, 2018

A compreensão de que a identidade categorial na qual a comunidade está inserida é ressignificada de diferentes formas pelo grupo pressupõe que existem formas variadas de esse mesmo grupo de posicionar nos diferentes espaços. A apropriação de determinadas habilidades e conhecimentos alinhados às diferentes percepções sobre lutas identitárias permitiu ao longo 


\section{Revista \\ Debates Insubmissos}

de suas trajetórias se lançar na defesa de diferentes projetos coletivos. Antes de se autorreconhecerem enquanto quilombolas, esses atores se reconheciam enquanto artesãos e, mesmo antes de se pensarem enquanto comunidade de artesãs quilombolas, se autodefiniam como agricultores. Nesse sentido, trata-se de identidades que se sobrepõem, entrecruzam-se e se acumulam, indicando assim a necessidade de uma análise por uma perspectiva multifacetada.

Em vista disso, é preciso ter noção de que, mesmo assumindo a classificação legal e normativa de remanescente de quilombo, o grupo continua agregando outros pertencimentos identitários. Partindo do entendimento de cultura enquanto produtora de comportamentos e ao mesmo tempo produto desses mesmos comportamentos sociais, torna-se coerente pensar nas identidades como agregados em movimento de velhos e novos pertencimentos, evidenciando a complexidade da alteridade (ENNES; MARCON, 2014). Portanto, isso demostra que, em suas interações, atores criam e recriam suas identidades, interpretam mudanças contextuais como oportunidades ou ameaças, apropriam-se de redes para mobilizar pessoas, negociam enquadramentos interpretativos que definem problemas e soluções e constroem uma linguagem para compreensão e definição do próprio confronto (DIANNI, 1992). Assim, a comunidade passa a vestir diferentes roupagens categoriais e identitárias para responder a determinadas demandas circunstanciais.

Com efeito, ao ampliar seus espaços de inserção social, o grupo passa a entender a necessidade de movimentações diversificadas dentro de contextos específicos. Enquanto agricultores, a comunidade possui uma série de lógicas de percepções que orienta suas ações internamente. As lideranças que representam a comunidade fora dos seus limites geográficos entendem que precisam costurar internamente alguns entendimentos e combinações a partir de diferentes demandas externas. Alguns entrevistados salientaram ao longo da pesquisa que não viam a necessidade de efetivar o reconhecimento legal da comunidade enquanto quilombola, pois enquanto agricultores já recebiam alguns benefícios do governo. Esses benefícios vão desde incentivos assistencialistas, como o Bolsa Família, até incentivos de insumos para plantação, como sementes.

Nesse sentido, existe outro fator envolvido: a questão das terras. A partir do momento em que a comunidade assume a categorização de quilombola, a titulação das terras passa a 


\section{Revista \\ Debates Insubmissos}

informar a condição de terra comunitária, ou seja, passa-se a desconsiderar as propriedades particulares sobre ela. Essa foi uma circunstância contenciosa que exigiu do grupo uma dinâmica relacional entre suas diferentes caracterizações identitárias. Enquanto o grupo avalia as garantias e ameaças de assumir determinados riscos e posicionamentos políticos, ela entende que precisa negociar internamente no intuito de preservar seus espaços de lutas, bem como suas conquistas materiais.

Dessa forma, a comunidade concorda em se autodeclarar remanescente de quilombo, mas estabelece limites internos para o alcance de tal categoria de identidade. Em outras palavras, o grupo converge para um reconhecimento identitário e étnico, no entanto, não concretiza a titulação das terras. As ameaças, caso o Incra fosse até a comunidade engrenar medições e inspeções para titulação da área, levam o grupo a ressignificar tal demanda contenciosa. Nesse caso, as lideranças conseguem estrategicamente manter as demandas relacionadas às lutas por reconhecimento dentro e fora das fronteiras da comunidade, mas de forma perspicaz também conseguem manter a coesão do grupo, permitindo alguns recuos, mesmo que temporários. Assim, as lideranças da Serra passam a defender seus interesses coletivos por meio de diferentes projetos e classificações categoriais. Um desses projetos que viabilizam a união do grupo em torno de sua mobilização identitária quilombola é o artesanato local.

Reconhecida enquanto comunidade artesã, a Serra conseguiu se projetar em alguns espaços sociais que posteriormente se tornarão estratégicos para seu reconhecimento quilombola. Em um primeiro momento, praticamente todo o artesanato produzido era direcionado para as feiras livres. Com o processo de reconhecimento institucional junto à Fundação Palmares, a relação estabelecida com o artesanato se torna completamente diferente. Esse é um aspecto da Serra das Viúvas, que perpassa quase todas as dimensões analíticas deste artigo, tendo em vista a sua importância para a configuração das transformações ocorridas na comunidade nos últimos anos. Devido às novas inserções sociais relacionadas ao seu reconhecimento institucional, o artesanato local passa a se projetar em uma diversidade de espaços sociais, sempre mediado por suas lideranças. 


\section{Revista \\ Debates Insubmissos}

O espaço que o artesanato ocupa na organização e na coesão do grupo pode ser percebido em suas influências nas outras dimensões da comunidade. Internamente, o grupo estabeleceu normas e regras pertinentes à produção artesanal, de forma que todos, de alguma forma, contribuam. Mesmo diante de circunstâncias tensas em relação à posse da terra, a comunidade consegue encontrar vias de manutenção dessas demandas envolvendo outros elementos no contexto. Assim, o que acontece é que cada família desenvolve um tipo de trabalho dentro dessa cadeia de produção artesanal. Não importa se um ou outro ficou receoso de se assumir negro quilombola ou se alguém discordou de abrir mão de seu pedacinho de terra:

Em relação a isso não. A gente não tem problema nenhum. Aqui todo mundo ajuda. Nessa hora ninguém fica criando problema, porque sabe que é uma coisa que vai trazer benefício pra todo mundo. Os homens vão pegar as palhas. Assim, vai mais homem porque o trabalho é duro. É longe. Mas vai mulher, também. Então, cada um pega as palhas de sua rocinha, prepara e traz. Algumas já fazem em casa, nas suas casas, mas o certo é todo mundo vim pra aqui. Então, tudo que a gente usa, sai daqui. Cada um faz sua parte. Porque você sabe, se não for assim, não dá certo. Uns não vão querer fazer sua parte e aí como é que vai ser? Se não tivesse essa organização, uns ia querer ganha mais do que outros (ENTREVISTA COM LIDERANÇA DA SERRA DAS VIÚVAS, REALIZADA DURANTE TRABALHO DE CAMPO).

Figura 04: Artesanato da Serra das Viúvas. Flor artesanal feita a partir da palha do milho roxo.

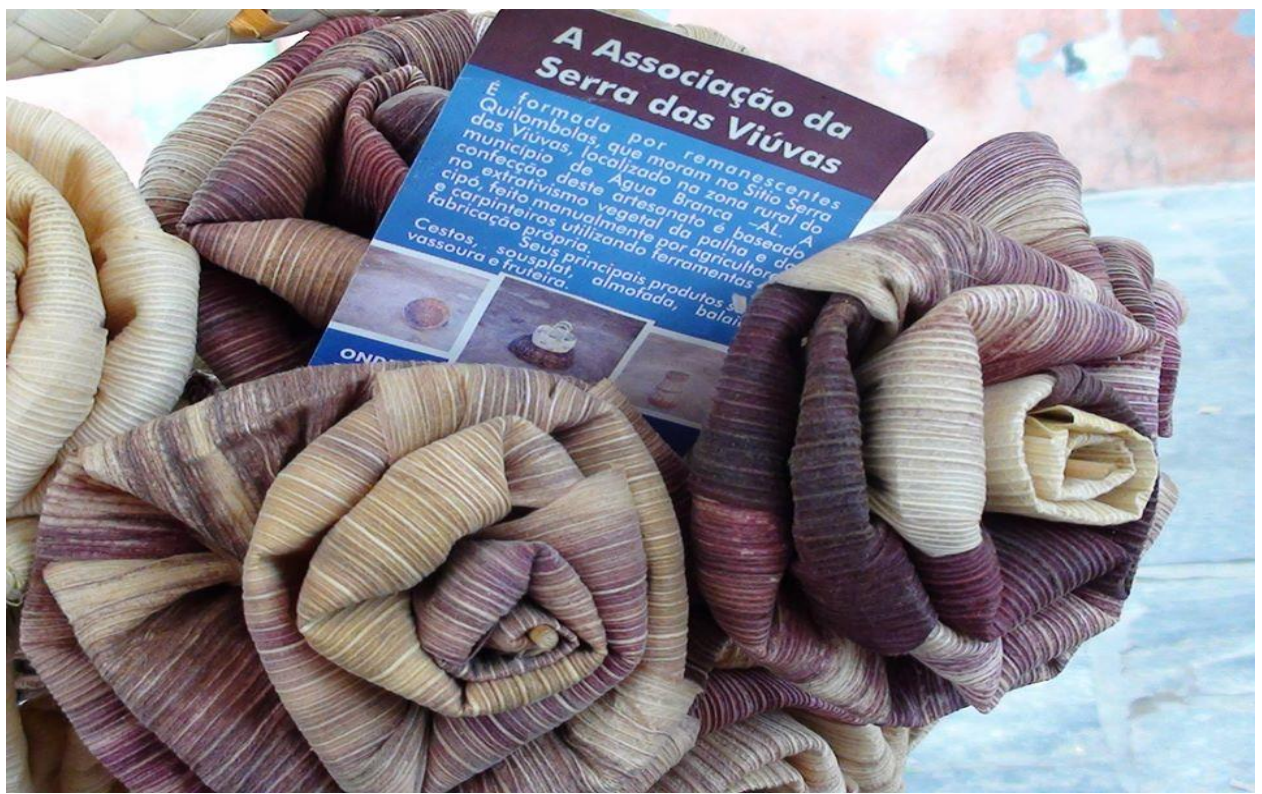

Fonte: Amaqui, 2016 


\section{Revista \\ Debates Insubmissos}

Nesse contexto, alguns vão para a mata colher as palhas de Ouricuri, que serve como matéria-prima de várias peças artesanais. Inclusive, essa é uma fase do trabalho que exige bastante resistência física, pois são cerca de quatro ou seis horas entre a ida até a plantação e a chegada na comunidade. Desse modo, a presença masculina nesse momento se faz mais presente. Além da palha do Ouricuri, o grupo passa a usar também outras matérias-primas, como a palha de milho. Assim, além de plantar, as famílias precisam preparar essas palhas para o beneficiamento junto à produção artesanal, o que envolve homens, mulheres e crianças; ou seja, o que se quer sublinhar aqui são acordos internos feitos pelo grupo para manter em evidência suas lutas e reivindicações coletivas e políticas, sem ameaçar a organização interna do grupo.

Dinâmicas como essas são possíveis a partir de articulações entre as lideranças e o grupo. É preciso que essas líderes tenham a visão do todo, ao mesmo tempo, a percepção das particularidades de interesses diferenciados. É em momentos como esses que tais lideranças acionam seus conhecimentos e recursos para buscar contornar as situações conflitivas e, ainda, propor alternativas de manutenção do grupo. Articula-se aqui as habilidades, maturidade, a tradição e respeito que lideranças mais velhas possuem junto ao grupo, com o conhecimento diversificado e entusiasmo de novas lideranças. Desse modo, em suas interações com realidades diversas, os atores à frente da comunidade acessam e internalizam diferentes conteúdos e experiências que irão compor seus repertórios de ações; interpretam mudanças contextuais como oportunidades ou ameaças, negociam circunstâncias interpretativas que definem conflitos ou soluções e constroem estratégias para direcionar tais contextos (TILLY, 1996; TARROW, 2013; DIANI, 1992).

O reconhecimento como remanescente de quilombo veio quase que concomitantemente com a legalização da Amaqui, a associação artesanal da comunidade. Como já salientado, a relação que se estabelece entre o reconhecimento identitário e o artesanato da comunidade permite sua projeção em espaços sociais diversos, inclusive, ampliação de suas redes de comunicação. As lideranças da Serra passam a ter essa noção de status identitário - nesse caso, étnico-cultural - e buscam assim articular diferentes projetos identitários categoriais em torno de suas lutas por reconhecimento e, também, redistributivos. Ter a habilidade de acessar e 
gonstats

conectar essas diferentes roupagens identitárias, tanto no âmbito dos conflitos internos da comunidade quanto nas transformações dos processos políticos externos ao grupo, exige uma articulação por parte dessas lideranças, de modo que suas próprias percepções acerca de suas identidades pessoais e coletivas são ressignificadas constantemente ao longo de tais processos.

A compreensão desses atores de que se faz necessário reconverter cenários de ameaças para cenários de possibilidades requer frequentes interações com diferentes esferas da sociedade mais ampla. $\mathrm{O}$ acúmulo de novas experiências e aproximações sociais diversas podem significar o fortalecimento político do grupo. Desse modo, as lideranças da comunidade demostram possuir credibilidade junto ao grupo para conduzir tais processos. A confiança atribuída a essas lideranças podem estar relacionadas também à confiança interpessoal entre seus membros, o que gera uma expectativa acerca da atitude esperada desses atores à frente da comunidade. Essa confiança se projeta em torno não apenas das competências que suas lideranças apresentam em defesa do grupo, mas também em torno das garantias institucionais interpretadas por elas.

Haveria, dessa forma, uma relação entre as estruturas institucionais e políticas e os recursos e conhecimentos pertencentes aos atores políticos. Isso significa afirmar que esses grupos organizados em torno de causas específicas são, em parte, resultado de mudanças estruturais, como também produtores e transformadores dessas mesmas estruturas políticas (TILLY, 1996; DIANI, 1992). Com isso, a comunidade Serra das Viúvas parece se movimentar dentro desses cenários de forma a manter suas relações de coesão, objetivando a ampliação de seus espaços de luta. $\mathrm{O}$ artesanato associado ao reconhecimento de uma identidade categorial demostrou ser uma importante estratégia de luta do grupo. Especificamente, as lideranças femininas responsáveis pela produção do artesanato ocupam lugar de destaque nessa dinâmica relacional, não apenas pela confecção em si dos produtos, mas também pelos elos que passam a firmar dentro e fora das fronteiras da comunidade. 


\subsection{Lideranças femininas, mercado étnico e transformações na comunidade quilombola serra das viúvas}

Figura 05: Lia, liderança quilombola da Serra das Viúvas, filha de Marlene, participando de entrevista para jornal local

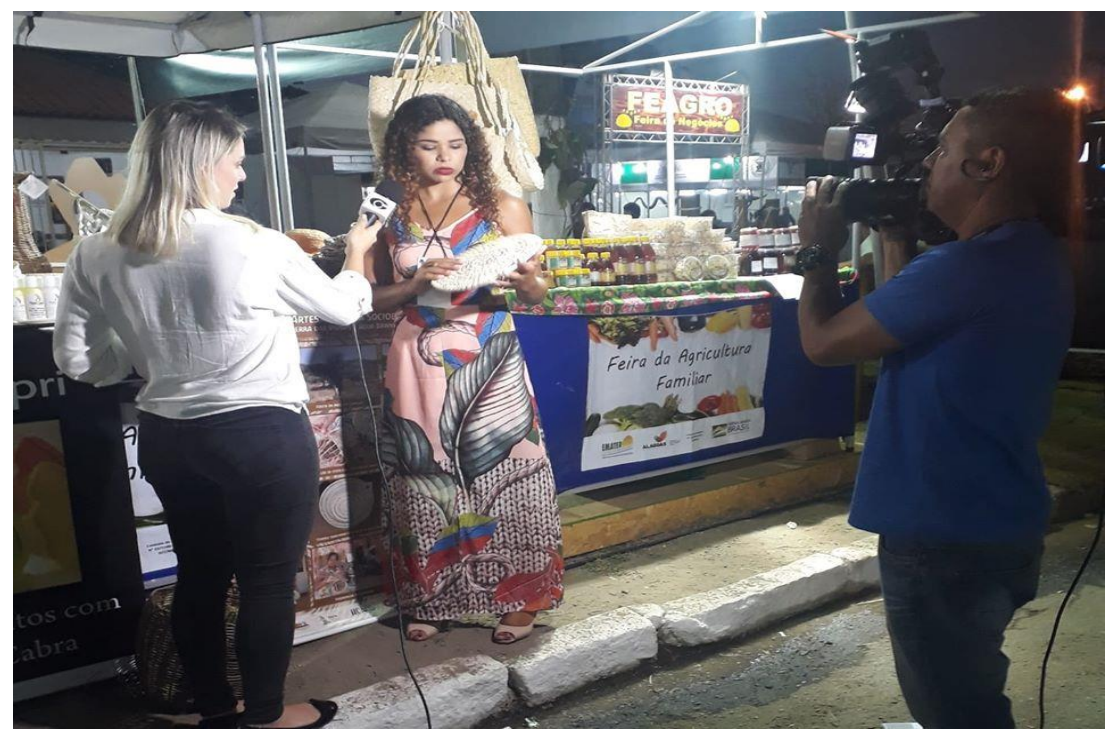

Fonte: Amaqui, 2014

A cada nova inserção, novas possibilidades de ganhos e garantias. Os conhecimentos adquiridos por meio de viagens, reuniões e encontros promovidos por grupos e instituições variadas permitiram a essas lideranças um acúmulo de novos conteúdos, que eram ressignificados para suas realidades coletivas e pessoais. Esses conhecimentos mais amplos e complexos, assimilados e redirecionados para seus interesses reivindicatórios, como algumas lideranças esclareceram nas entrevistas, viabilizaram a aproximação do grupo com espaços antes não vislumbrados por eles. Isso significa que a cada nova assimilação de conhecimentos novos interessas são agregados às suas mobilizações coletivas, pois as ações de engajamento precisam ser pensadas a partir do interesse que envolve os atores nesses grupos (YONG, 2000).

Tal dinâmica de reconversão de conhecimento e saberes em estratégias de movimentação e aproximação de novos atores ficou evidenciada quando uma das lideranças mais antigas da comunidade explicita a presença de sua filha, uma das líderes mais jovens e atuantes do grupo, em momentos importantes para a comunidade. A própria liderança jovem, 


\section{Revista \\ Debates Insubmissos}

que é estudante, demostra existir uma relação de fortalecimento de suas competências para assumir ações à frente do grupo. $\mathrm{O}$ que indica outra retribuição ligada aos conhecimentos e saberes adquiridos em suas experiências, que é o status que elas ocupam dentro e fora dos limites da comunidade. Embora existam questões a se discutir acerca das diferentes percepções que coexistem na comunidade sobre os papéis que essas líderes desempenham, sobretudo dentro dos seus círculos mais pessoais, destaca-se que em relação às demandas das lutas e reivindicações de reconhecimento e de demandas materiais para a comunidade, essas mulheres possuem seus espaços bem delimitados no grupo.

Essa visibilidade na comunidade conquistada por essas mulheres, está diretamente relacionada às suas construções de percepções de mundo e de vida. Ao valorizar e preservar os conhecimentos tradicionais perpetuados por diferentes gerações, essas líderes mulheres conseguem dar sentido às suas reivindicações coletivas. Elas se tornam representantes de seus símbolos identitários, quando resguardam saberes tradicionais no âmbito religioso, artístico por meio do artesanato étnico e de suas danças características, ou ainda, por meio de seus conhecimentos de medicina popular onde se destacam as benzedeiras, assim como, seus conhecimentos de ervas medicinais. Sendo assim, "elas tornam-se muito frequentemente lideranças comunitárias, senão no âmbito político, ao menos na esfera simbólica” (NEVES, 2019, pg. 98).

Desse modo, essas lideranças quilombolas por meio de seus saberes e habilidades herdadas por gerações de tradições étnicas, passam a desenvolver junto ao grupo, uma linguagem confiável e capaz de ser compreendida. As lideranças mais experientes se mostram mais habilidosas para conduzir diálogos e tomadas de decisão nos espaços internos da comunidade, sobretudo pela credibilidade e confiança conferida a essas mulheres ao enxergar nelas iguais pertencimentos culturais, sobretudo em suas formas comunicativas. Com isso, essas mulheres quilombolas são investidas pelo grupo com o status de liderança por meio de suas habilidades diversas acumuladas ao longo de suas experiencias de vida. Esses saberes e habilidades ligadas uma linguagem da herança tradicional, no caso da Serra das Viúvas se complementam com novos saberes advindos de novas inserções sociais. 


\section{Revista \\ Debates Insubmissos}

Como demonstrado aqui, lideranças mais jovens se mostram, também guardiãs de seus pertencimentos culturais e identitários, no entanto trazem para essas formas de luta, novas possibilidades de reinvindicação a partir de conhecimentos garimpados em suas trajetórias diversas como a trajetória escolar e as experiências políticas, por exemplo. Diante do entendimento da necessidade crescente de formas de resistência cerca das injustiças sociais e de precariedade em suas realidades (COUTO, 2002; NEVES, 2019), essas jovens mulheres quilombolas, ressignificam os conteúdos e experiências adquiridas fora dos espaços da comunidade para fortalecimento de suas estratégias de ação política. Então, a Serra das Viúvas compõe um repertorio de mobilização composto por saberes e conhecimentos diversos advindos de apropriações feitas por essas mulheres numa simbiose entre o novo e o tradicional, conseguindo dessa forma, tanto se comunicar com o grupo ao qual pertencem por meio de uma linguagem étnica e cultural, mas também avançar em suas lutas identitárias e redistributivas.

Sendo assim, as transformações ocorridas na Serra das Viúvas, também perpassam por transformações simbólicas e, sobretudo políticas. Essas mulheres em suas diferentes gerações conquistam visibilidade junto ao grupo e a sociedade mais ampla, usando suas armas nessas arenas de disputas por poder. Conhecimentos étnico-culturais aliados a novos saberes permitem que essas lideranças e projetem nos espaços sociais e políticos, muitas vezes dominados pela figura masculina (TUBALDINI, 2010). Por meio das lutas por reconhecimento étnico e racial as mulheres da Serra conseguem trazer transformações sócio-econômicas para o grupo, mas também para suas próprias trajetórias enquanto mulheres artesã quilombolas. Assim, essas mulheres por meio de trabalho artesanal acabam tendo um papel simbólico e político de destaque no processo de construção e de consolidação das identidades quilombolas que por sua vez, estão relacionados ao acesso à terra e aos bens ofertados pelo Estado. A ascensão dessas mulheres enquanto líderes desse coletivo, indica serem o reconhecimento social e cultural aqui agregado ao um fazer artesanato étnico, uma estratégia de empoderamento feminino possível somente em espaços de significações de pertencimentos culturais baseados no pertencimento étnico e racial (CRENSHAW, 2002).

Todas as habilidades, saberes e técnicas que elas vão acumulando ao longo de suas trajetórias permitiram que essas lideranças fossem se projetando dentro da comunidade ao 


\section{Revista \\ Debates Insubmissos}

mostrarem direcionamentos de ações e resultados para as demandas do grupo. Assim, faz sentido pensar em toda essa rede de relação e comunicação como espaço promissor para aquisição não só de novos recursos sociais, mas também de possíveis retribuições simbólicas e materiais. Ainda se referindo às aproximações relacionais criadas entre esses atores sociais, esta pesquisa indica haver garantias e ofertas ligadas a tais interações sociais. A aquisição, segundo os entrevistados, de cestas básicas, cisternas, material de construção e também material escolar, demostra que os ganhos materiais envolvidos nessa dinâmica reivindicatória da Serra estão relacionados à melhora de suas condições de sobrevivência. Nos "tempos bons" ou "no tempo de Lula", como denominam as entrevistadas, com o dinheiro que elas conseguiam nas feiras mais importantes ou com grandes encomendas, relatam com alegria a oportunidade de conseguir comprar, inclusive, eletroeletrônicos, como televisão, rádio, geladeira e celular.

Mesmo a comunidade ainda se encontrando em circunstâncias de desfavorecimento econômico e social, a pesquisa demonstrou que suas ações voltadas para o reconhecimento identitário, dentro de determinados contextos propícios, permitiram a conquista de alguns bens distributivos que podem ser entendidos como transformações em suas condições socioeconômicas. Dessa forma, os ganhos simbólicos e matérias que passaram a contribuir com as transformações identitárias e matérias do grupo ocorreram e continuam a ocorrer ao longo de sua constituição enquanto comunidade quilombola. Assim, o artesanato local vai se constituindo enquanto dimensão importante para ampliar essas ofertas e garantias, sem comprometer a coesão do grupo. Os usos que a comunidade faz de seu artesanato diretamente ligado à sua identidade quilombola apontam para reconversões sociais cruciais nessa obtenção de garantias.

Além de diversificar e ampliar as redes de contato que a comunidade possui, o artesanato étnico conferiu meios de superar alguns dos seus conflitos internos e, ainda, direcionar interesses diversos para objetivos comuns, como melhoria de suas condições de vida. Dessa forma, o empenho de todos junto à produção artesanal local permitiu a obtenção, dentre outras coisas, de retribuições simbólicas e econômicas. A comunidade passa a ser conhecida cada vez mais e a ter um alcance ainda mais amplo. A diversificação em suas formas de produção e oferta de seus produtos artesanais permite não só conhecer e se aproximar de novos 


\section{Revista \\ Debates Insubmissos}

atores sociais, mas também receber melhores pagamentos por suas peças, como demonstrado em algumas entrevistas.

Assim, o artesanato vai se configurando como um eixo norteador de seus objetivos capaz de agregar diferentes desejos e interesses e, ainda, manter coesa a comunidade em meio a circunstâncias contenciosas. Toda essa rede de relações e de comunicação, que aproximou a comunidade de realidades antes não conhecidas ou mesmo difíceis de serem acessadas, projetase para o grupo como reflexo concreto das garantias institucionais. Isso porque coletivos sociais como esse são em parte um produto de mudanças em sistemas de políticas institucionalizadas, bem como produtores dessas mesmas políticas (MCADAM, 1996; TARROW, 2013).

A trajetória de formação e constituição da Serra das Viúvas enquanto comunidade quilombola - que envolve desde a aceitação de tal caracterização categorial por parte de seus moradores até a reestruturação de formas organizacionais internas - não deve ocultar suas dinâmicas e rearranjos desenvolvidos em meio aos conflitos envolvidos em tais processos. A comunidade não deve ser entendida como uma homogeneidade e consenso acerca de sua "identidade quilombola" ou quanto à sua "ancestralidade escravocrata", questões já suscitadas anteriormente. No entanto, em meio às circunstâncias de não concordância e conflitos, o coletivo consegue desenvolver formas de convivência e organização que ao mesmo tempo atendem a um objetivo maior de adesão a uma categorização étnica necessária e também aos interesses mais pessoais e subjetivos de seus participantes.

A construção de uma consciência coletiva categorial para uma formação política e social reconhecida e garantida, institucionalmente falando, demonstra que a comunidade converge para o mesmo objetivo, em se tratando de garantias de direitos sociais, mesmo com entendimentos muitas vezes diferenciados. Desde questões complexas e delicadas - como o autorreconhecimento enquanto quilombola descendente de escravos ou mesmo se autodefinir como negro - até as históricas e conflitivas questões agrárias, a comunidade demostra interessantes e dinâmicas estratégias de coesão e continuidade, mesmo vivenciando tensões e discordâncias em relação a tais problemáticas. Agregar toda a comunidade em torno do artesanato, de modo que cada um, cada família tem um papel a desempenhar e um espaço a 


\section{Revista \\ Debates Insubmissos}

ocupar, parece ter sido a forma encontrada pelo grupo para se sobrepor aos conflitos e manter o coletivo coeso.

Sua diversificada rede de relação conectada a uma complexa malha de comunicação atuante em diferentes espaços sociais, públicos e privados, garantiu ao grupo desenvolver seu artesanato como elo entre todos esses elementos, a princípio antagônicos, mas necessários. Desse modo, fatores que muitas vezes são analisados enquanto duais e contraditórios como o Estado e os movimentos sociais, o latifundiário e o agricultor, as técnicas modernas e tecnológicas e a tradição cultural, no caso da Serra das Viúvas apontam para uma complexa interação entre tais fatores, dentro de condições específicas.

Todos esses elementos compõem a realidade na qual se assenta a comunidade hoje enquanto remanescente quilombola. A Amaqui representa uma organização em torno de lutas por reconhecimento étnico e de bens materiais, impactando em suas condições de desigualdade social e econômica. Parte-se do princípio de que as esferas econômicas e culturais se interconectam nas mais variadas e dinâmicas formas de constituição de ação coletiva ou luta por direitos sociais (YONG, 2000). Assim, o artesanato ressignificado enquanto artesanato étnico inserido num mercado de bens simbólicos, indica representar para a comunidade tanto o enfrentamento de seus conflitos internos quanto uma estratégia de enfrentamento das situações de constrangimento social e desigualdades materiais em meio a arenas de desiguais distribuições de poder. Desse modo, tais vínculos contribuíram para a redefinição das percepções a respeito das condições de manutenção e de sobrevivência do grupo, bem como a adesão à categoria quilombola como uma nova possibilidade de definiçãa de vida desse coletivo.

\section{CONCLUSÃO}

Com isso, a comunidade Serra das Viúvas, inserida nesse cenário de mudanças, internaliza essas mudanças de forma a ressignificar algumas dimensões importantes à organização e permanência do grupo. As lutas por reconhecimento identitário defendidas pela comunidade passam a ter suas diretrizes organizadas também a partir de mudanças nos 


\section{Revista \\ Debates Insubmissos}

contextos políticos mais amplos. Com as aberturas políticas no arcabouço institucional do país, entendimentos de garantias e estabilidade (TILLY, 1996; TARROW, 2013) são captados pelo grupo de forma a direcionar suas ações.

Em vista disso, esse cenário de aberturas e garantias é internalizado pela comunidade como gatilhos para definição de fronteiras e espaços de poder em torno de suas reivindicações políticas por reconhecimento; desde redefinições dos papéis de certos atores externos ao grupo até o que poderia parecer, num primeiro momento, um "recuo", mas que no entendimento deste artigo se torna ressignificações de possíveis ameaças. Ou seja, quando o Estado institucionaliza garantias e direitos inerentes aos coletivos enquadrados na categoria identitária de remanescentes de quilombo, não é somente em relação aos posicionamentos de autorreconhecimento que essas comunidades precisam se firmar, mas também acerca de outras questões importantes dentro do grupo, como demandas redistributivas envolvendo inclusive suas terras.

Nesse mesmo cenário de movimentações estratégicas em torno de reafirmações de espaços de ação política e de poder, a Serra das Viúvas se projeta enquanto coletivo coeso em torno de seus pertencimentos identitários e territoriais. Desse modo, a Serra das Viúvas se empodera de seus saberes e habilidades acumulados ao longo de suas experiências diversas e as reconverte em importantes trunfos nesse jogo de poder e autoafirmação. Assim, a garantia dos direitos do grupo, inclusive agrários, passa prioritariamente pelo reconhecimento de sua condição identitária. Isso porque a identidade se define a partir de interações e diálogos com o outro e, por sua vez, com as expectativas e construções que esse estabelece em relação a nós, e por vezes em luta com tais "essencializações" identitárias (TAYLOR, 1994; HONNETH, 2003).

Desse modo, destaca-se aqui a ocupação do espaço de empoderamento por parte das mulheres da Serra das Viúvas enquanto lideranças. Os impactos de transformações estruturais nos comportamentos e direcionamentos de ações coletivas levaram à constituição de recursos e habilidades acionados por essas lideranças em suas lutas políticas. Os seus saberes herdados e reproduzidos em gerações, associados a novos conhecimentos e técnicas adquiridos em novas 


\section{Revista \\ Debates Insubmissos}

experiências, somam-se à ampliada rede de relações, que permite a esse grupo inserções sociais e políticas cada vez mais vastas.

Assim, essas mulheres despontam em circunstâncias de empoderamento como líderes de demandas políticas e econômicas dentro de seu grupo. Esta pesquisa aponta então, para uma relação entre domínios de saberes e empoderamento feminino (CRENSHAW, 2002; NEVES, 2019; TUBALDINI, 2010). A visibilidade que essas líderes mulheres passam a ter dentro e fora de seus limites territoriais, está diretamente relacionada aos diversificados espaços sociais nas quais estão envolvidas. Sendo assim, estar inserida em tais circunstâncias, podem lhes fornecer trunfos, saberes, conhecimentos que lhe direcionam para um certo reconhecimento e status diferenciado.

Ao superar o dilema de aceitar ou rejeitar a titulação das terras enquanto "terras de remanentes de quilombo", o que inevitavelmente levaria essas áreas à condição de comunitária (pauta de conflitos internos no grupo), as lideranças direcionam tal circunstância contenciosa para o desenvolvimento do grupo por meio de trabalho coletivo, sobretudo direcionado para o artesanato local. Nesse caso, as lideranças estrategicamente conseguem manter as demandas relacionadas às lutas por reconhecimento dentro e fora das fronteiras da comunidade, mas de forma perspicaz também conseguem manter a coesão do grupo, permitindo alguns recuos, mesmo que temporários. Dessa forma, as lideranças da Serra passam a defender seus interesses coletivos por meio de diferentes projetos e classificações categoriais.

Evidencia-se assim, uma forma diferenciada de luta pela terra e pelo território quilombola. A comunidade encontra conexões entre diferentes dimensões de sua realidade para compor estratégias de mobilizações políticas e identitárias. Conhecimentos, saberes, técnicas e habilidades garimpadas ao longo de suas trajetórias, associados a contextos de garantias, permite que essas lideranças redirecionem seus possíveis conflitos para cenários de possibilidades. A comunidade assim, evidencia esse entendimento ao fortalecer seu artesanato étnico projetando-o fora dos limites espaciais da comunidade em meio eficientes movimentações políticas e sociais. Desse modo, o artesanato local passa a desempenhar um papel crucial dentro desse coletivo quando permite a garantia de gratificações simbólicas como status, conhecimentos e habilidades inovadoras, bem como a possibilidade de garantias 


\section{Revista \\ Debates Insubmissos}

materiais e econômicas como o aumento da renda dessas famílias e até o acesso a produtos industrializados antes não possíveis de serem consumidos.

A percepção aqui é de que todas essas dimensões estão entrelaçadas em suas configurações e direcionamentos. A pesquisa conseguiu evidenciar que todas essas dimensões acabam sendo influenciadas e orientadas pelo artesanato quilombola. Não se trata simplesmente de mencionar uma comunidade que se junta para produzir seu artesanato tradicional, mas demonstrar as lógicas e percepções envolvidas nesse fenômeno presente na Serra das Viúvas. $\mathrm{O}$ artesanato étnico demostrou ser um importante e estratégico eixo norteador de vários processos de mobilização e organização ocorridos dentro da comunidade. Inclusive, como uma referência de identificação para essas lideranças artesãs dentro e fora do grupo. Com efeito, o artesanato se projeta enquanto gatilho de orientações pessoais e coletivas em torno de lutas por reconhecimento e possíveis retribuições redistributivas.

O resultado dessas movimentações, que não podem ser entendidas aqui como “aleatórias" ou "desinteressadas" (GAXIE, 1977), são dinâmicas específicas de enfrentamento a diferentes formas de injustiça e constrangimentos sociais. No mesmo bojo dessas ações, o grupo entende que lutas por justiça social não inviabilizam movimentações por ganhos distributivos. E isso ficou evidenciado neste artigo quando, diante de circunstâncias de abertura ou ameaça, o grupo se apropriava de saberes e competências específicas às suas vivências para encontrar alternativas que o favorecessem. Os ganhos advindos dessas aproximações de atores e espaços variados vão desde ganhos simbólicos como status, novos conhecimentos, ampliação de redes de contato e reconhecimento, até ganhos materiais como cestas básicas, cisternas, dinheiro e material de construção.

Nesse sentido, significa afirmar que entre essas estratégicas alternativas se encontra o artesanato étnico, que passa a ser ressignificado a partir da aproximação do grupo com orientações mais mercadológicas. Não se trata aqui de verificar acertos e erros das escolhas desse coletivo, mas compreender os tipos de percepção que esses atores criaram de suas realidades. Desse modo, o artesanato étnico enquanto eixo de coesão da comunidade, demonstra estar em dinâmica e constante ressignificação, numa relação direta e multidimensional com suas lutas por reconhecimento identitário. A Serra das Viúvas, então, encontra no 
reconhecimento identitário étnico e cultural, atrelado ao fazer artesanal quilombola, uma estratégia de enfrentamento tanto de seus conflitos internos quanto das situações de constrangimento e desigualdade social.

\section{REFERÊNCIAS}

ANJOS, Gabriele dos. Liderança de Mulheres em Pastorais e Comunidades Católicas e suas retribuições. Porto Alegre. Cadernos Pagu(31), julho/dez, 2008.

ARRUTI, José Maurício. Mocambo: Antropologia e História do Processo de Formação Quilombola. Bauru, São Paulo, Edusp. 2006.

BOURDIEU, Pierre. A Representação política. Elementos para uma teoria do Campo Político. In: BOURDIEU, Pierre. O Poder Simbólico. Rio de Janeiro: Bertrand Brasil, 1998.

BOURDIEU, Pierre. É Possível um Ato Desinteressado? In: BOURDIEU, Pierre. Razões Práticas: sobre a teoria da ação. Campinas: Papirus, 1996, p.137-197.

BOYER, Véronique. A construção do objeto quilombo. Da categoria colonial ao conceito antropológico. In: Antropolítica. Niterói, n. 27, 2009, p. 131-153.

COUTO, Márcia Thereza. Na trilha do gênero: pentecostalismo e CEBs. Revista Estudos Feministas, vol. 10, n⿳0 2, Florianópolis, 2002, pp.357-369.

CRENSHAW, Kimberlé. Documento para o encontro de especialistas em aspectos da discriminação racial relativos ao gênero. Estudos Feministas, 1/2002.

DIANI, M. The concept of social movement. The Sociological Review, Keele, v. 40, n. 1, p. $1-25,1992$.

ELIAS, Norbert, O Processo Civilizador, 2 vols. Rio de Janeiro: Jorge Zahar, 2001.

ENNES, Marcelo Alario. MARCON, Frank. Das identidades aos processos identitários: repensando conexões entre cultura e poder. Sociologias, Porto Alegre, ano 16, no 35, jan/abr 2014, p. 274-305.

GAXIE, D. Èconomie das Partis ET rétributions do militantisme. Revue Française de Science Politique, n. 1,v. 27, 1977.

HONNETH, Axel. Luta por Reconhecimento: A Gramática Moral dos Conflitos Sociais. São Paulo, Ed. 34, 2003.

LEITE, Ilka Boaventura. Os Quilombos no Brasil: questões conceituais e normativas. Revista Etnográfica. Vol. IV (2). 2000. p. 333-345.

MELO, Nailma Rodrigues Vieira. Juventude e território quilombola. O caso da Serra das Viúvas. Ufal. Delmiro Gouveia-Al. 2019.

MCADAM, D.; TARROW, S.; TILLY, C. To map contentious politics. Mobilization: An International Quarterly, San Diego, v. 1, n. 1, p. 17-34, 1996. 
MCADAM, Doug; TARROW, Sidney. Movimentos Sociais e Eleições: por uma compreensão mais ampla do contexto político da contestação relação entre movimentos e política eleitoral. Sociologias. Porto Alegre, ano 13, n. 28, set./dez. 2011.

NEVES, Paulo S. C. Luta anti-racista: entre Reconhecimento e Redistribuição. Rev. bras. Ci. Soc. vol.20 no.59 São Paulo Oct. 2005.

NEVES, Paulo S. C. Reconhecimento ou Redistribuição: O que o debate entre Honneth e Fraser diz das lutas sociais e vice-versa. Política \& Sociedade - Florianópolis - Vol. 17 - No 40. P. 234-257- Set./Dez. de 2018.

NEVES, Paulo S. C. A questão quilombola sob o prisma do gênero, ou como a busca identitária inverte lógicas do poder masculino: um estudo de caso. Revista Fórum Identidades. Itabaiana- SE. Universidade Federal de Sergipe, v. 30, nº 01, p. 97-111, jul.-dez. de 2019.

RAMOS, Graciliano. Cangaços. Rio de Janeiro: Record, 2014.

RENAULT, Emmanuel (2004) "Reconnaissance, Institutions, Injustice" in: Revue du MAUSS (De la Reconnaissance: Don, Identité e Estime de Soi), n² 23, pp. 180-195.

RUGIU, A. Nostalgia do mestre artesão. Campinas, Autores Associados, 1998.

SANDEL, Michael. Liberalism and the Limits of Justice, Cambridge, University Press. 1982.

SILVA, Aline Ferreira da. Etnodesenvolvimento Quilombola no Governo Lula. 2011. 193

f. Dissertação (Mestrado em Sociologia). Programa de Pós-graduação em Sociologia-PPGS. Universidade Federal de Sergipe. São Cristóvão.

SOUZA, Patrícia Borba de; ARAÚJO, Klariene Andrielly. A Mulher Quilombola: da Invisibilidade à Necessidade por Novas Perspectivas Sociais e Econômicas In: ESTEVES, Juliana Teixeira; BARBOSA, José Luciano Albino; FALCÃO, Pablo Ricardo de Lima (Orgs.). Direitos, gênero e movimentos sociais II. Florianópolis: CONPEDI, 2014.

STAVENHAGEN, R. Etnodesenvolvimento: uma dimensão ignorada no pensamento desenvolvimentista. Anuário Antropológico. Tempo Brasileiro. Rio de Janeiro. 1984.

TARROW, S. The language of contention: revolutions in words 1688-2012. Cambridge: Cambridge University Press, 2013.

TAYLOR, Charles. Multiculturalism and the "Politics of Recognition", Princeton, Princeton University Press. 1992.

TAYLOR, Charles. Multiculturalismo: examinando a política de reconhecimento. Lisboa: Instituto Piaget, 1994.

THOMPSON, John B. Ideologia e cultura moderna: teoria social crítica na era dos meios de comunicação de massa. Petrópolis, RJ: Vozes, 1995. 
TUBALDINI, Maria Aparecida dos Santos. O trabalho pluriativo da mulher quilombola na recuperação ambiental e manutenção da família no Vale do Rio Doce/MG. $4^{\circ}$ Encontro da rede de estudos rurais, Curitiba/PR 2010.

YOUNG, Iris Marion. Representação Política, Identidade e Minorias. Do original (Capítulo 4) Inclusion and democracy. Oxford University Press. Lua Nova. Tradução de Alexandre Morales. 2000.

Submetido: $17 / 06 / 2020$

Aprovado: 05/10/2020 